\title{
GUGATAN NAFKAH TANPA CERAI
}

\author{
Indriana Ertanti. ${ }^{1}$ Imam Makhali. $^{2}$ \\ Fakultas Hukum Universitas Islam Kadiri \\ Jln. Sersan Suharmaji No. 38, Manisrenggo, Kota Kediri, Jawa Timur, Indonesia. \\ ertaindriana4@gmail.com
}

\begin{abstract}
The purpose of this research is to conduct a deep overview legal on legal protection for wives who are not sufficiently maintained by their husband. The research method employed was normative. The results of this study indicates that if any one party neglect their obligation -in this case a husband does not provide maintenance to his wife-then the wife could send a claim to the court. This claim should contain a formal claim letter completed with evidence of her husband's income. In the case when marriage books are with the husband, the wife could send request for marriage book duplicates from catatan sipil where marriage was held. Evidence for maintenance claim should also include the amount of money that a husband should provide for their wife and children. A wife could propose other evidences such as two witnesses, a husband's payroll check and other evidence which support her claim that her husband is financially capable to provide the needed maintenance for the family.
\end{abstract}

Keywords: maintenance claim; without divorce; spouse.

\begin{abstract}
ABSTRAK
Tujuan penelitian ini untuk mengkaji secara mendalam perlindungan hukum bagi istri yang tidak mendapatkan nafkah dari suami serta untuk menganalisa upaya yang seharusnya dilakukan oleh seorang istri apabila tidak memperoleh nafkah dari suami. Metode penelitian ini menggunakan penelitian hukum normatif. Adapun hasil penelitian ini menjelaskan bahwa ketika suami tidak memberikan nafkah kepada istri sesuai dengan Pasal 34 ayat (3) UndangUndang Nomor 1 Tahun 1974 tentang Perkawinan yang menyebutkan bahwa apabila salah satu pihak didalamnya yaitu suami melalaikan kewajibannya yaitu enggan melaksanakan kewajibannya untuk memberi nafkah kepada istri, maka istri dapat mengajukan gugatan nafkah ke Pengadilan. Kemudian gugatan nafkah diajukan dengan surat gugatan yang memuat fakta dan alasan istri menggugat, dengan menyertakan surat nikah sebagai bukti serta bukti-bukti terkait penghasilan suami. Terkait pembuktian surat nikah, apabila surat nikah tersebut ada di tangan suami, kemudian seorang istri dapat meminta duplikat atau salinannya di kantor catatan sipil tempat perkawinan tersebut dilaksanakan. Pembuktian gugatan nafkah meliputi juga jumlah penghasilan suami dan nafkah yang diperlukan untuk diberikan untuk istri dan anak. Istri dapat mengajukan bukti-bukti berupa keterangan 2 (dua) orang saksi, slip gaji suami, dan bukti lainnya, yang menunjukkan sebenarnya suami mempunyai kemampuan untuk memberikan nafkah serta berapa besaran nafkah yang dibutuhkan untuk diberikan kepada istri dan anak.
\end{abstract}

Kata kunci : Gugatan Nafkah; Tanpa Cerai; Suami-istri.

\footnotetext{
${ }^{1}$ Submit : 8-Juli-2019 | Review-1 : 12-September-2019 | Review-2 : 13-9-2019 | Production :
} 01 November 2019. 


\section{Pendahuluan}

Perkawinan sangat penting dalam kehidupan manusia karena dengan perkawinan yang sah mengakibatkan pergaulan antara laki-laki dan perempuan menjadi terhormat sesuai dengan kedudukan manusia sebagai mahluk yang terhormat. Pergaulan hidup berumah tangga dibina dalam suasana damai, tentram dan kasih sayang antara suami dan istri. Sementara anak hasil keturunan perkawinan sah yang menghiasi kehidupan berumah tangga merupakan perhiasan kehidupan berumah tangga sekaligus merupakan kelangsungan hidup manusia secara bersih dan terhormat. ${ }^{2}$

Menurut Pasal 1 Undang-Undang Nomor 1 Tahun 1974 tentang Perkawinan memberikan definisi bahwa perkawinan adalah ikatan lahir batin antara seorang pria dengan seorang wanita sebagai suami istri dengan tujuan membentuk keluarga (rumah tangga) yang bahagia dan kekal berdasarkan ke Tuhanan Yang Maha Esa. Perumusan yang diberikan Pasal 1 Undang-Undang Nomor 1 Tahun 1974 tentang Perkawinan, bukan saja memuat pengertian atau arti perkawinan itu sendiri, melainkan juga mencantumkan tujuan dan dasar perkawinan. Pengertian perkawinan ialah ikatan lahir batin antara seorang pria dengan seorang wanita sebagai suami istri, sedangkan tujuannya membentuk keluarga atau rumah tangga yang bahagia dan kekal yang didasarkan kepada ketuhanan Yang Maha Esa atau jika dihubungkan dengan Pasal 2 ayat (1) Undang-Undang Nomor 1 Tahun 1974 tentang Perkawinan didasarkan kepada hukum agamanya atau kepercayaan agamanya masing-masing.

Berbeda dengan Kompilasi Hukum Islam (KHI) yang secara spesifik meletakan perkawinan itu sebagai salah satu ibadah muamalah. Ketentuan dalam Pasal 2 dan Pasal 3 Kompilasi Hukum Islam menyatakan: "Perkawinan menurut hukum Islam adalah pernikahan, yaitu akad yang sangat kuat atau miitsaqon ghaalidhan untuk mentaati perintah Allah dan melaksanakannya merupakan ibadah yang bertujuan untuk mewujudkan kehidupan rumah tangga yang sakinah, mawaddah, dan rahmah".

2 Tri Lisiani Prihatinah, "Tinjauan Filosofis Undang-Undang Nomor 1 Tahun 1974," Jurnal Dinamika Hukum, 8, no. 2 (2008). Hlm. 167 
Menurut Amir Syarifuddin sebuah perkawinan memiliki tujuan diantaranya yaitu untuk membentuk keluarga bahagia yang penuh ketenangan hidup dan rasa kasih sayang. Hal ini terlihat dari Firman Allah dalam Surat Ar-Rum ayat 21 yang artinya:

"Di antara tanda-tanda kekuasaan-Nya ialah Dia menciptakan untukmu istri-istri dari jenismu sendiri, supaya kamu menemukan ketenangan padanya dan menjadikan di antaramu rasa cinta dan kasih sayang. Sesungguhnya pada yang demikian itu benar-benar menjadi tanda-tanda bagi kaum yang berpikir". 3

Dalam menjalankan perkawinan ada beberapa prinsip yang perlu diperhatikan agar sebuah perkawinan benar-benar berarti dalam hidup manusia. Adapun prinsip-prinsip tersebut diantaranya adalah prinsip bahwa seorang suami merupakan penanggung jawab dalam rumah tangga. Dalam hal ini meskipun suami dan isteri masing-masing mempunyai hak dan kewajiban, namun suami mempunyai kedudukan lebih dari isteri karena suami adalah pemimpin rumah tangga.

Suami istri wajib saling cinta-mencintai, hormat menghormati, setia dan memberi bantuan lahir batin yang satu kepada yang lainnya (Pasal 33 UndangUndang Perkawinan). Suami adalah kepala keluarga dan istri ibu rumah tangga (Pasal 31 Undang-Undang Perkawinan). Suami diberkewajiban oleh UndangUndang untuk melindungi istrinya dan memberikan segala sesuatu keperluan hidup berumah tangga sesuai dengan kemampuan suami.

Demikian juga istri yang diwajibkan oleh Undang-Undang untuk mengatur urusan rumah tangga sebaik-baiknya (Pasal 34 Undang-Undang Perkawinan). Tanggung jawab istri untuk mengatur urusan rumah tangga sebaik-baiknya, bukan berarti membakukan peran perempuan hanya pada ranah domestik, dan laki-laki pada ranah publik. Demikian pula kedudukan suami sebagai kepala keluarga, bukan berarti kedudukan perempan berada di bawah kedudukan laki-laki. Sebagai institusi paling independen, keluarga memiliki otoritas absolut dalam mengatur perjalanan roda rumah tangganya. Tidak ada satupun kekuatan luar sekalipun itu

${ }^{3}$ Amir Syarifuddin, Hukum Perkawinan Islam Di Indonesia Antara Fiqh Munakahat Dan Undang-Undang Perkawinan (Jakarta: Kencana, 2007). Hlm. 46-47 
pemerintah yang memiliki otoritas penuh untuk melakukan intervensi terhadap satu keluarga, kecuali atas ijin keluarga yang bersangkutan. ${ }^{4}$

Sebagai seorang penengaggung jawab dalam rumah tangga, seorang suami juga memiliki kewajiban, salah satunya yaitu memberikan nafkah terhadap anak dan istri seperti yang termuat dalam Pasal 34 ayat (1) Undang-Undang Nomor 1 Tahun 1974 tentang Perkawinan yang menyatakan bahwa :

"Suami wajib melindungi isterinya dan memberikan segala keperluan hidup berumah tangga sesuai dengan kemampuannya”.

Ini berarti bahwa suami berkewajiban penuh memberikan nafkah bagi keluarganya (anak dan istri). Ketentuan ini merupakan konkeskuensi dari ketentuan yang menetapkan suami sebagai kepala keluarga dan isteri sebagai ibu rumah tangga serta pengurus rumah tangga sebagaimana yang ditentukan oleh Pasal 31 ayat (3) Undang-Undang Nomor 1 Tahun 1974 tentang Perkawinan.

Nafkah berarti "belanja". Maksudnya ialah sesuatu yang diberikan seseorang kepada istri, kerabat dan miliknya sebagai keperluan pokok bagi mereka. Keperluan pokok, seperti makanan, pakaian dan tempat tinggal. ${ }^{5}$

Nafkah merupakan kewajiban suami terhadap isterinya dalam bentuk materi, karena kata nafkah itu sendiri berkonotasi materi. Sedangkan kewajiban dalam bentuk non materi, seperti memuaskan hajat seksual isteri tidak termasuk dalam artian nafkah, meskipun dilakukan suami terhadap isterinya. Kata yang selama ini digunakan secara tidak tepat untuk maksud ini adalah nafkah batin sedangkan dalam bentuk materi disebut nafkah lahir. Dalam bahasa yang tepat nafkah itu tidak ada lahir atau batin, namun yang ada adalah nafkah yang yang bersifat lahiriah atau materi. ${ }^{6}$

Nafkah merupakan kewajiban suami yang harus diberikan kepada istri. Didalam hukum islam dan Undang-Undang Perkawinan, bahwasannya nafkah tetap menjadi kewajiban mutlak suami yang harus diberikan kepada istri, dan apabila istri bekerja membantu mencari nafkah untuk keluarganya, maka nafkah

\footnotetext{
${ }^{4}$ Tri Lisiani Prihatinah, “Tinjauan Filosofis Undang-Undang Nomor 1 Tahun 1974.” Hlm. 169

${ }^{5}$ Departemen Agama RI, Ilmu Fiqh, Jilid II (Jakarta: Ditjen Binbaga Islam, 1984). hlm. 184

6 Amir Syarifuddin, Hukum Perkawinan Islam Di Indonesia Antara Fiqh Munakahat Dan Undang-Undang Perkawinan. Hlm. 165
} 
tersebut tidak menggugurkan kewajiban suami untuk memberikan nafkah kepada istri. Dijelaskan pula didalam hukum islam dan Undang-Undang Perkawinan bahwasannya istri yang bekerja tetap berkewajiban menjalankan kewajibannya sebagai seorang istri, yang mana kewajibannya ialah untuk mengurus rumah tangga.

Menurut Pasal 34 ayat (1) Undang-Undang Nomor 1 Tahun 1974 tentang Perkawinan, baik nafkah istri maupun anak adalah menjadi tanggung jawab suami atau ayah dari anak-anak. Pasal 34 ayat (3) Undang-Undang Perkawinan menyatakan bahwa jika suami atau istri melalaikan kewajibannya masing-masing, maka dapat mengajukan gugatan ke Pengadilan.

Seorang suami sesuai dengan penghasilannya, suami menanggung (1) Nafkah, kiswah dan tempat kediaman bagi isteri (2) Biaya rumah tangga, biaya perawatan dan biaya pengobatan bagi anak isterinya dan (3) Biaya pendidikan bagi anak.

Persoalannya, praktiknya terkadang dalam kehidupan berumah tangga tidak selalu berjalan pada tujuan yang diharapkan, seperti kasus yang terjadi di Cimahi Bandung pada tahun 2003, gugatan nafkah pernah diajukan seorang istri yang bersuamikan seorang pengusaha. Sang istri menilai, suaminya tak menafkahinya secara layak, padahal dari segi finansial sang suami sangat mapan. Kedua pihak, melalui pengacaranya masing-masing, bersidang di Pengadilan Agama (PA) Cimahi.

Setelah sidang pembuktian, Majelis Hakim, menyimpulkan bahwa sang suami sebenarnya mampu menafkahi istrinya secara layak, karena itu hakim memutuskan mengabulkan gugatan nafkah tersebut dan sang suami harus membayar nafkah yang dilalaikannya. ${ }^{7}$

Kasus diatas tentu saja berbeda dengan beberapa kasus yang selama ini terjadi pada umumnya dimana biasanya pengajuan gugatan nafkah dilakukan bersama pengajuan gugatan cerai dan setelah terjadinya perceraian.

7 http://www.hukumonline.com/berita/baca/hol17429/kejarlah-nafkah-sampai-ke-pengadilan, diakses tanggal 19 Agustus 2018 
Ketentuan yang termuat dalam Pasal 34 ayat (1) Undang-Undang Nomor 1 Tahun 1974 menjelaskan bahwa seorang suami memiliki kewajiban untuk memberikan nafkah kepada istri sesuai dengan kemampuan yang dimilikinya, namun apabila suami yang memiliki kemampuan memberi nafkah enggan melaksanakan kewajibannya untuk memberikan nafkah kepada istri maka sesuai dengan ketentuan yang termuat dalam Pasal 34 ayat (3) Undang-Undang Nomor 1 Tahun 1974 yang menjelaskan bahwa apabila salah satu pihak melalaikan kewajibannya maka pihak yang dirugikan dapat mengajukan gugatan ke Pengadilan.

Kasus yang terjadi di Pengadilan Agama Cimahi ini berbeda dengan penyelesaian kasus pada umumnya, dimana faktor nafkah ataupun ekonomi biasanya dijadikan alasan untuk bercerai, dan tuntutan nafkah menjadi salah satu tuntutan yang diajukan. Penyelesaian gugatan nafkah berbeda pada letak pengajuan gugatan nafkah, dimana dalam kasus ini gugatan nafkah diajukan didalam ikatan perkawinan dengan menggunakan bukti-bukti bahwa suami sebenarnya mampu untuk menafkahi namun melalaikan kewajiban menafkahi.

Berdasarkan penjelasan di atas, maka pembahasan utama yang dikaji dalam penelitian ini adalah bagaimana upaya yang seharusnya dilakukan oleh seorang istri ketika tidak mendapatkan nafkah lahir dari suami, yang dalam posisi ini suami tersebut sebenarnya mampu untuk memberikan nafkah yang belanja dan perawatan rumah tangga kepada istri.

Penelitian yang membahas tentang gugatan nafkah secara umum cukup banyak dilakukan oleh para peneliti terdahulu. Berdasarkan hasil penelusuran terhadap beberapa literatur yang telah dilakukan, maka setidaknya ditemukan beberapa literatur, baik berupa jurnal yang membahas mengenai permasalahan ini.

Pertama, Ari Dewi Ernawati dengan judul Tinjauan Hukum Islam Tentang Gugatan Terhadap Nafkah Anak Setelah Perceraian (Studi Analisis Putusan Pengadilan Agama Purwokerto Nomor : 2848/Pdt.G/2014/PA.PWT). Dalam penelitiannya membahas tentang bagaimana pandangan fiqh dan hukum positif terhadap putusan Pengadilan Agama Purwokerto nomor: 2848/Pdt.G/2014/PA.PWT tentang gugatan nafkah anak setelah perceraian. 
Adapun penelitian ini menggunakan metode Metode kepustakaan (library research).

Kedua, Anugrah Putra Adinugroho dengan judul Gugatan Pembayaran Nafkah Madliyah Oleh Bekas Istri Karena Kelalaian Bekas Suami (Studi Putusan Pengadilan Agama Jember Nomor : 1843/Pdt.G/2007/PA.Jr.). Dalam penelitiannya membahas tentang apakah hak-hak seorang istri yang perkawinannya putus karena perceraian, apakah bekas istri dapat menuntut bekas suami yang melalaikan kewajibannya memberi nafkah sesudah perceraian serta apa pertimbangan hukum Hakim Pengadilan Agama dalam memutus perkara nomor : 1843/Pdt.G/2007/PA.Jr. Adapun metode penelitian yang digunakan yaitu metode yuridis normatif, dengan menelaah dan mengkaji pada kasus tertentu saja (case approach) yaitu pada putusan Pengadilan Agama Nomor : 1843/Pdt.G/2007/PA.Jr.

Berdasarkan kedua penelitian terdahulu tersebut, maka dapat diketahui bahwa penelitian ini berbeda dengan penelitian tersebut. Adapun perbedaan tersebut terletak pada fokus kajian atau rumusan masalah yang ditawarkan. Seperti yang diketahui bahwa rumusan masalah dalam penelitian pertama mengkaji masalah pandangan figh dan hukum positif terhadap putusan Pengadilan Agama Purwokerto nomor: 2848/Pdt.G/2014/PA.PWT tentang gugatan nafkah anak setelah perceraian. Kemudian pada penelitian kedua membahas tentang hak-hak seorang istri yang perkawinannya putus karena perceraian serta pertimbangan hukum Hakim Pengadilan Agama dalam memutus perkara nomor : 1843/Pdt.G/2007/PA.Jr. Berbeda dengan dua rumusan masalah tersebut penelitian ini memfokuskan kajian pada perlindungan hukum bagi istri yang tidak mendapatkan nafkah yang layak dari suami serta upaya yang seharusnya dilakukan oleh seorang istri apabila tidak memperoleh nafkah yang layak dari suami. 


\section{Rumusan Masalah}

Berdasarkan permasalahan yang telah dijelaskan di atas, maka batasan masalah dalam penelitian ini, yaitu bagaimana perlindungan hukum bagi istri yang tidak mendapatkan nafkah materi dari suami serta bagaimanakah upaya hukum yang seharusnya dilakukan oleh seorang istri apabila tidak memperoleh nafkah materi dari suami.

\section{Tujuan Penelitian}

Adapun tujuan penelitian ini adalah untuk mengkaji secara mendalam perlindungan hukum bagi istri yang tidak mendapatkan nafkah materi dari suami serta untuk menganalisa upaya yang seharusnya dilakukan oleh seorang istri apabila tidak memperoleh nafkah materi dari suami.

\section{Metode Penelitian}

Jenis penelitian ini menggunakan penelitian hukum normatif yang menelaah makna yang terkandung dalam Pasal 34 ayat (1) dan (3) Undang-Undang nomor 1 Tahun 1974 tentang Perkawinan. Hal tersebut diperlukan agar terdapat batasan yang jelas antara konsep nafkah yang dimaksud oleh seorang suami dengan konsep nafkah yang dimaksud oleh sorang istri.

Untuk bahan hukum, penelitian ini menggunakan bahan hukum primer, sekunder dan bahan non-hukum. Adapun bahan hukum primer merupakan bahan hukum yang bersifat autoritatif artinya mempunyai otoritas. Bahan hukum primer terdiri dari perundang-undangan, catatan-catatan resmi atau risalah dalam pembuatan Undang-Undang dan putusan-putusan hakim. Untuk bahan hukum primer yang memiliki otoritas tertinggi adalah Undang-Undang Dasar (UUD) karena semua peraturan di bawahnya baik isi maupun jiwanya tidak boleh bertentangan dengan UUD. Bahan hukum primer yang selanjutnya adalah Undang-Undang. Dalam penelitian ini yang menjadi bahan hukum tesebut adalah Undang-Undang Nomor 1 Tahun 1974 tentang Perkawinan. Bahan hukum sekunder adalah semua publikasi tentang hukum yang bukan merupakan dokumen-dokumen resmi. Publikasi tentang hukum meliputi buku-buku teks, 
kamus-kamus hukum, jurnal-jurnal hukum, dan komentar-komentar atas putusan pengadilan. Dalam penelitian ini yang menjadi bahan hukum skunder, berupa buku-buku, artikel, jurnal ataupun karya ilmiah lain yang terkait dengan penelitian ini. Kemudian untuk bahan non-hukum, berupa kamus bahasa, kamus hukum, serta bahan-bahan bantu lain sebagai pendukung penelitian.

Analisa dalam penelitian ini menggunakan analisis deduktif, yaitu sebuah analisa yang menggunakan penalaran atau proses berpikir yang bertolak dari kesimpulan khusus dari premis yang lebih umum. jika premis benar dan cara penarikan kesimpulannya sah, maka dapat dipastikan hasil kesimpulannya benar. Dalam penalaran, proposisi yang dijadikan dasar penyimpulan disebut dengan premis (antesedens) dan hasil kesimpulannya disebut dengan konklusi (consequence). ${ }^{8}$

\section{Hasil Penelitian dan Pembahasan}

\subsection{Perlidungan Hukum Bagi Istri yang Tidak Memperoleh Nafkah dari Suami}

Nafkah adalah sebuah kebutuhan dan keperluan yang berlaku menurut keadaan dan tempat, seperti makanan, pakaian, rumah, dan sebagainya. Banyaknya nafkah yang diwajibkan adalah sekedar mencukupi keperluan dan kebutuhan serta mengingat keadaan dan kemampuan orang yang berkewajiban menurut kebiasaan masing-masing tempat ${ }^{9}$

Nafkah wajib bagi istri selama ia menunaikan berbagai tanggungan. Istri memenuhi batasan-batasan fitrahnya. Jika istri menyimpang dari aturan, melampaui suami dalam tujuan kehidupan berumah tangga maka istri tidak mendapatkan nafkah. ${ }^{10}$ Nafkah yang menjadi kewajiban suami merupakan hak istri, sedangkan kepatuhan istri kepada suami adalah kewajiban istri dan hak suami. Dimana jika seorang istri tidak patuh pada suami, secara tidak

\footnotetext{
${ }^{8}$ Bandur and Agustinus, Penelitian Kualitatif Metodologi, Desain Dan Teknik Analisi Data Dengan NVIVO10 (Jakarta: Mitra Wacana Media, 2014). Hlm. 26

${ }^{9}$ Wasman and Wardah Nuroniah, Hukum Perkawinan Islam Di Indonesia, Perbandingan Fikih Dan Hukum Positif (Yogyakarta: Teras, 2011). Hlm. 252

${ }^{10}$ Ali Yusuf As- Subki, Fiqh Keluarga: Pedoman Berkeluarga Dalam Islam (Terjemahan) (Jakarta: Amzah, 2010). Hlm. 187
} 
langsung suami juga punya hak tidak memberikan nafkah kepada istri. Karena hak dan kewajiban berjalan beriringan.

Bila seorang istri bekerja di luar rumah dalam pekerjaan yang halal dan dilakukan atas persetujuan suami, istri tetap berhak mendapatkan nafkah , sebab istri dalam posisi tetrtawan oleh suami, tetapi apabila wanita itu bekerja tanpa seizin suami dan bahkan istri tersebut dilarang, maka hak nafkahnya terhapus karena penawananya disini sudah berkurang. ${ }^{11}$

Dalam Undang-Undang Nomor 1 Tahun 1974 tentang Perkawinan dan Kompilasi Hukum Islam, setelah terjadinya perkawinan yang sah maka menimbulkan hak dan kewajiban antara suami dan istri. Diantaranya pihak istri mendapatkan nafkah dari pihak suami yang menikahinya, sebaliknya di atas pundak suami terletak kewajiban untuk menafkahi istrinya.

Undang-Undang Nomor 1 Tahun 1974 tentang Perkawinan tidak didapati istilah nafkah. ${ }^{12}$ Walaupun tidak ditemukan istilah nafkah, tetapi dalam salah satu pasal di Undang-Undang Nomor 1 Tahun 1974 tentang Perkawinan mengatur tentang masalah nafkah. Masalah nafkah hanya diatur dalam Pasal 34 ayat (1) disebutkan: suami wajib melindungi istrinya dan memberikan segala sesuatu keperluan hidup berumah tangga dengan kemampuannya.

Ketentuan ini merupakan konsekuensi dari ketentuan yang menetapkan suami sebagai kepala rumah tangga serta mengurus rumah tangga sebagaimana yang ditentukan oleh Pasal 31 ayat (3). Sebenarnya jika ditilik lebih jauh, pembagian peran ini akan menimbulkan ketergantungan secara ekonomi bagi pihak perempuan. Akibat lebih jauhnya, perempuan dalam hal ini yaitu isteri tidak memiliki akses ekonomi yang sama dengan suami dimana isteri tidak memiliki kekuatan untuk memaksa suami memberikan nafkah yang cukup untuk keluarganya.

\footnotetext{
${ }^{11}$ Syaikh Mahmud Al-Mashri, Perkawinan Idaman (Terjemahan) (Jakarta: Qitho Press, 2011). Hlm. 122

${ }^{12}$ Abdul Manan, Penerapan Hukum Acara Perdata Di Lingkungan Pradilan Agama (Jakarta: Prenada Media Group, 2005). Hlm. 441
} 
Menurut Pasal 34 ayat (1) Undang-Undang Nomor 1 Tahun 1974 tentang Perkawinan, baik nafkah isteri maupun anak adalah menjadi tanggung jawab suami atau ayah dari anak-anak. Pasal 34 ayat (3) UndangUndang Perkawinan menyatakan bahwa jika suami atau isteri melalaikan kewajibannya masing-masing dapat mengajukan gugatan ke Pengadilan.

Berikut ini disebutkan satu persatu mengenai jenis khusus dan bentukbentuk kelalaian, diantaranya yaitu: ${ }^{13}$

5.1.1. Lalai dalam soal menegakan rumah tangga yang sakinah, mawaddah, dan warahmah.

5.1.2. Tidak seimbangnya antara hak dan kewajiban antara kedudukan suami istri dalam pergaulan hidup bersama, dan dalam kehidupan rumah tangga, hidup berakibat salah satu dirugikan karenanya.

5.1.3. Lalai dalam soal kepemimpinan keluarga. Suami adalah kepala keluarga dan ibu adalah ibu rumah tangga.

5.1.4. Tidak saling mencintai dan tidak saling menghormati, tidak setia dan tidak saling memberikan bantuan lahir batin yang satu dengan yang lain(suami dan istri).

5.1.5. Lalai dalam soal tempat kediaman yang tetap yang ditentukan oleh suami istri bersama.

5.1.6. Lalai dalam soal mengasuh, memelihara dan membimbing anak-anak, baik pertumbuhannya maupun agamanya. 
5.1.7. Salah satu pihak melakukan perbuatan hukum yang merugikan suami atau istri.

5.1.8. Suami tidak melindungi dan tidak memberikan keperluan hidup berumah tangga, padahal ia berkemampuan.

5.1.9. Suami tidak memberikan bimbingan kepada istrinya, tidak memberikan pendidikan agama, dan tidak memberikan kesempatan belajar pengetahuan yang berguna atau bermanfaat bagi agama, nusa dan bangsa.

5.1.10. Suami tidak menanggung dan tidak bertanggung jawab dalam soal nafkah, pakaian dan tempat kediaman, biaya rumah tangga, biaya perawatan, biaya pengobatan bagi istri dan anak serta biaya pendidikan anak.

5.1.11. Suami tidak berlaku adil kepada istri-istrinya dan anak-anaknya baik soal nafkah, soal pembagian waktu giliran menginap malam (bagi yang berpoligami).

Seorang suami sesuai dengan penghasilannya, suami menanggung (1) Nafkah, kiswah dan tempat kediaman bagi isteri (2) Biaya rumah tangga, biaya perawatan dan biaya pengobatan bagi anak isterinya (3) Biaya pendidikan bagi anak, namun demikian, pada praktiknya terkadang tidaklah selalu sesuai seperti yang termuat dalam peraturan perundang-undangan di atas.

Kelalaian suami dengan tidak memberikan nafkah berimbas pada keberlangsungan istri untuk mengatur urusan rumah tangga dengan mengesampingkan meskipun istri tersebut memiliki penghasilan sendiri, hal ini tidak menggugurkan kewajiban mutlak seorang suami untuk tetap 
memberikan nafkah seperti yang telah disebutkan pada Kompilasi Hukum Islam (KHI) pasal 80 ayat (4) huruf a dan b berbunyi :

"Sesuai dengan penghasilannya suami menanggung: a. nafkah, kiswah dan tempat kediaman bagi isteri; b. biaya rumah tangga, biaya perawatan dan biaya pengobatan bagi isteri dan anak."

Terkait dengan upaya hukum yang harus ditempuh istri dalam mengugat nafkah keperluan rumah tangga adalah dengan mengajukan gugatan nafkah ke Pengadilan Agama. Dalam hal ini, seorang hakim dapat memutus perkara gugatan nafkah dengan ketentuan bahwa seorang suami yang melalaikan kewajiban nafkah tersebut bisa dijadikan sebagai utang suami terhadap istri, jika memang istri tersebut belum mampu untuk membiayai kehidupan sendiri. Menurut Satria Effendi yang mengutip pendapat Wahbah Zuhaili, dimana seorang hakim dapat menetapkan bahwa suami yang tidak melaksanakan kewajiban nafkah istri sebagai bagian dari utang yang harus ditunaikan, dan dalam hal ini hakim dapat mengizinkan jika terdapat permohonan dari istri tentang adanya hutang suami terhadap nafkah istri yang belum dibayar oleh suami. ${ }^{14}$

Fungsi dan peran suami dan istri yang telah ditetapkan dalam UndangUndang Nomor 1 Tahun 1974 tentang Perkawinan yaitu pemeliharaan dilakukan oleh suami adalah pemberian biaya terkait perannya sebagai kepala rumah tangga, sedangkan istri adalah pengatur biaya yang diberikan oleh suami untuk anak dan keluarga terkait perannya sebagai ibu rumah tangga.

Dengan demikian, kewajiban dan tanggung jawab kewajiban yang dimaksud dalam Pasal 80 ayat (4) huruf a dan b Kompilasi Hukum Islam (KHI) tentunya merefleksi pembagian kewajiban dan tanggung jawab antara suami atau ayah dan istri atau ibu terhadap anak (apabila dalam perkawinan tersebut terdapat anak), kecuali si istri atau ibu adalah orang tua tunggal.

${ }^{14}$ Satria Effendi, Problematika Hukum Keluarga Islam Kontemporer, (Jakarta: Kencana Prenada Media Group, 2004). Hlm. 162-163 
Kewajiban seorang laki-laki yang telah terikat perkawinan adalah sebagai suami yang menjadi kepala rumah tangga memberikan nafkah bagi istri. Apabila suami lalai dalam melaksanakan kewajibannya berdasarkan Pasal 34 ayat (3) Undang-Undang Nomor 1 Tahun 1974 tentang Perkawinan, maka istri dapat mengajukan gugatan kepada pengadilan sesuai Pasal 34 ayat (3) Undang-Undang Nomor 1 Tahun 1974 tentang Perkawinan yang menyatakan :

"Jika suami atau istri melalaikan kewajibannya masing-masing dapat mengajukan gugatan kepada Pengadilan”.

Pasal 34 ayat (1) Undang-Undang Nomor 1 Tahun 1974 hanya mengatur terkait seorang suami wajib melindungi istrinya dan memberikan segala sesuatu keperluan hidup berumah tangga sesuai dengan kemampuannya, dimana yang artinya ialah suami berkewajiban memberikan nafkah kepada istri untuk kemudian digunakan mengatur urusan rumah tangga sebaik-baiknya. Terkait permintaan pemberian nafkah biaya rumah tangga dan biaya pemeliharaan harus melalui perceraian terlebih dahulu atau tidak, Undang-Undang Nomor 1 Tahun 1974 tidak menentukan demikian. Undang-Undang Nomor 1 Tahun 1974 hanya mengatur apabila suami lalai memberikan nafkah terhadap istri maka istri bisa menggugat ke pengadilan.

Sebagaimana kasus yang terjadi di Cimahi Bandung pada tahun 2003, gugatan nafkah pernah diajukan seorang istri yang bersuamikan seorang pengusaha. Sang istri menilai, suaminya tak menafkahinya secara layak, padahal dari segi finansial sang suami sangat mapan. Kedua pihak, melalui pengacaranya masing-masing, bersidang di Pengadilan Agama (PA) Cimahi.

Setelah sidang pembuktian, Majelis Hakim, menyimpulkan bahwa sang suami sebenarnya mampu menafkahi istrinya secara layak, karena itu hakim memutuskan mengabulkan gugatan nafkah tersebut dan sang suami harus membayar nafkah yang dilalaikannya. ${ }^{15}$

\footnotetext{
${ }^{15}$ http://www.hukumonline.com/berita/baca/hol17429/kejarlah-nafkah-sampai-ke-pengadilan, diakses tanggal 19 Agustus 2018
} 
Kasus diatas jelas bertentangan dengan Pasal 34 ayat (1) UndangUndang Nomor 1 Tahun 1974 tentang Perkawinan dimana seorang suami memiliki kewajiban untuk memberikan nafkah untuk memenuhi kebutuhan hidup berumah tangga sesuai dengan kemampuannya. Hal ini tentu merupakan bentuk kelalaian suami kepada istri sebagai ibu rumah tangga yang berkewajiban mengatur segala urusan rumah tangga, bentuk kelalaian tersebut yaitu suami tidak melindungi dan tidak memberikan keperluan hidup berumah tangga, padahal ia berkemampuan.

Hakim Agung Mahkamah Agung, Andi Syamsu Alam, mengatakan bahwa hal positif dibolehkannya gugatan nafkah adalah utuhnya biduk rumah tangga. Hakim selaku pemutus sengketa selalu menekankan agar pasangan suami istri yang ingin bercerai membatalkan niatnya, yang paling penting dalam gugatan nafkah adalah pembuktian. Harus jelas berapa penghasilan suami dan berapa nafkah yang dibutuhkan untuk diberikan kepada istri dan anak. ${ }^{16}$ Maka dapat ditarik kesimpulan bahwa seorang istri dapat mengajukan gugatan nafkah terhadap suami dengan meminta pula biaya pemeliharaan terhadap anak sebagai kewajiban suami atau ayah terhadap anak.

\subsection{Upaya Hukum yang Seharusnya Dilakukan oleh Seorang Istri Apabila} Tidak Memperoleh Nafkah dari Suami.

Pengadilan merupakan lembaga hukum (tempat seseorang mengajukan permohonan keadilan). ${ }^{17}$ Tujuan dari lembaga tersebut secara umum adalah mengadili setiap perkara yang diajukan, karena perkara yang dimaksudkan telah merugikan hak-hak seseorang terhadap orang lain, khususnya mengenai hak-hak keperdataan. Pada prinsipnya, di Indonesia

\footnotetext{
${ }^{16}$ https://www.hukumonline.com/klinik/detail/ulasan/lt54dc068b67d8e/bisakah-mengajukangugatan-nafkah-tanpa-cerai, diakses tanggal 3 April 2019

${ }^{17}$ Basiq Djalil, Peradilan Agama Di Indonesia; Gemuruhnya Plitik Hukum (Hk. Islamm Hk. Barat, Dan Hk. Adat) Dalam Rentang Sejarah Bersama Pasang Surut Lembaga Peradilan Agama Hingga Lahirnya Peradila Syari'at Islam Aceh, (Jakarta: Kencana Prenada Media Group, 2006). Hlm. 2
} 
ada dua peradilan yang mempunyai kewenangan menyelesaikan perkara perdata, yaitu Peradilan Umum dan Peradilan Agama. ${ }^{18}$

Apa yang dituntut oleh penggugat disebut gugatan sedangkan apa yang diminta oleh pemohon disebut permohonan, biasa juga disebut surat gugatan dan surat permohonan. ${ }^{19}$ Bila mana cara mengajukan gugatan dan sampai dimana batas-batas tanggung jawab suami dan istri yang dapat dituntut pelaksanaanya belumdiatur dalam dalam Peraturan Pemerintah Nomor 9 Tahun $1975 .^{20}$

Gugatan nafkah diajukan dengan surat gugatan yang memuat fakta dan alasan istri menggugat, dengan menyertakan surat nikah sebagai bukti serta bukti-bukti terkait penghasilan suami. Terkait pembuktian surat nikah, apabila surat nikah tersebut ada di tangan suami, kemudian seorang istri dapat meminta duplikat atau salinannya di kantor catatan sipil tempat perkawinan tersebut dilaksanakan. ${ }^{21}$ Pembuktian gugatan nafkah meliputi juga:

\subsubsection{Jumlah penghasilan suami.}

5.2.2. Nafkah yang dibutuhkan untuk diberikan untuk istri dan anak.

Istri dapat mengajukan bukti-bukti berupa keterangan 2 (dua) orang saksi, slip gaji suami, dan bukti lainnya, yang menunjukkan sebenarnya suami mempunyai kemampuan untuk memberikan nafkah serta berapa besaran nafkah yang dibutuhkan untuk diberikan kepada istri dan anak. ${ }^{22}$

Kasus di Pengadilan Agama Cimahi merupakan salah satu kasus gutatan nafkah yang gugatannya dikabulkan oleh Hakim Pengadilan Agama Cimahi, yang kemudian setelah adanya putusan yang inkracht maka

18 Fakultas Hukum Universtas Gadjah Mada, dimuat dalam artikel, di akses melalui: http://law.ugm.ac.id/?P=1067 , pada tanggal 3 April 2019

${ }^{19}$ Erfaniah Zuhriah, Peradilan Agama Indonesia Sejarah Pemikiran Dan Realita (Malang: UIN Malang Press, 2009). Hlm. 224

20 Mohd. Idris Ramulyo, Hukum Perkawinan Islam Suatu Analisis Dari Undang-Undang Nomor 1 Tahun 1974 Dan Kompilasi Hukum Islam (Jakarta: PT Bumi Aksara, 2002). Hlm. 188

${ }^{21}$ https://www.hukumonline.com/klinik/detail/ulasan/lt54dc068b67d8e/bisakah-mengajukangugatan-nafkah-tanpa-cerai, diakses tanggal 3 Maret 2019

${ }^{22}$ Ibid 
perlu adalah eksekusi. Dalam buku Pedoman Pelaksanaan Tugas dan Administrasi Peradilan Agama, dinyatakan bahwa eksekusi merupakan salah satu bentuk sita jaminan atau sita revindicatoir yang telah dinyatakan sah dan berharga dalam putusan yang berkekuatan hukum tetap, dimana sita eksekusi hanya menyangkut pembayaran sejumlah uang. ${ }^{23}$

Dalam Keputusan Ketua Mahkamah Agung Nomor 026/KMA/ SK/II/2012 Tentang Standar Pelayanan Peradilan, tepatnya ketentuan mengenai Pelayanan Administrasi Eksekusi, dinyatakan bahwa masyarakat yang telah memiliki putusan pengadilan yang berkekuatan hukum tetap dapat mengajukan permohonan eksekusi atas putusan tersebut. Permohonan tersebut diajukan kepada Ketua Pengadilan Negeri. Dalam hal ini, pihak Pengadilan kemudian menetapkan biaya panjar eksekusi yang ditentukan dalam SKUM yang berisi komponen biaya eksekusi, di antaranya yaitu biaya materai penetapan eksekusi, biaya pemberitahuan aanmaning atau teguran tertulis kepada termohon eksekusi, dan biaya pelaksanaan eksekusi (terdiri dari biaya pelaksanaan eksekusi atau pengosongan, biaya sita eksekusi/angkat sita/CB). ${ }^{24}$

Dalam buku "Pedoman Pelaksanaan Tugas dan Administrasi Peradilan Agama”, yang dikeluarkan oleh Mahkamah Agung RI, secara rinci menetapkan prosedur pelaksanaan eksekusi sebuah putusan Pengadilan. ada 20 (dua puluh) poin pelaksanaan eksekusi putusan yang telah ditetapkan oleh Mahkamah Agung, yaitu sebagai berikut:

5.2.1. Apabila pihak yang dikalahkan tidak mau melaksanakan isi putusan secara suka rela, maka pihak yang menang dapat mengajukan permohonan eksekusi kepada Pengadilan Agama yang memutus perkara.

\subsubsection{Asas Eksekusi}

\footnotetext{
${ }^{23}$ Mahkamah Agung RI, Pedoman Pelaksanaan Tugas Dan Administrasi Peradilan Agama; Buku II, (Jakarta: Direktorat Jenderal Badan Peradilan Agama, 2013). Hlm. 117

${ }^{24}$ Keputusan Ketua Mahkamah Agung Nomor 026/KMA/ SK/II/2012 Tentang Standar Pelayanan Peradilan.
} 
a. Putusan telah berkekuatan hukum tetap, kecuali putusan serta merta, putusan provisi dan eksekusi berdasarkan groze akte (Pasal 180 HIR/Pasal 191 RBg dan Pasal 224 HIR/Pasal $250 \mathrm{RBg}$ ).

b. Putusan tidak dijalankan secara sukarela.

c. Putusan mengandung amar condemnatoir (menghukum).

d. Eksekusi dipimpin oleh Ketua Pengadilan Agama dan dilaksanakan oleh Panitera.

5.2.3. Eksekusi terdiri dari 2 (dua) jenis, yaitu:

a. Eksekusi riil dapat berupa pengosongan, penyerahan, pembagian, pembongkaran, berbuat sesuatu atau tidak berbuat sesuatu dan memerintahkan atau menghentikan sesuatu perbuatan (Pasal 200 ayat (11) HIR/Pasal 218 ayat (2) RBg/Pasal $1033 \mathrm{Rv}$ ).

b. Eksekusi pembayaran sejumlah uang (executie verkoof) dilakukan melalui mekanisme lelang (Pasal 196 HIR/Pasal 208 RBg).

\subsubsection{Prosedur Eksekusi}

a. Pemohon mengajukan permohonan eksekusi dan mekanismenya sebagaimana diatur dalam pola bindalmin dan peraturan terkait.

b. Ketua Pengadilan Agama menerbitkan penetapan untuk aanmaning, yang berisi perintah kepada Jurusita supaya memanggil Termohon eksekusi hadir pada sidang aanmaning.

c. Jurusita/Jurusita Pengganti memanggil Termohon eksekusi.

d. Ketua Pengadilan Agama melaksanakan aanmaning dengan sidang insidentil yang dihadiri oleh Ketua, Panitera dan Termohon eksekusi. Dalam sidang aanmaning tersebut: (1) Seyogyanya Pemohon eksekusi 
dipanggil untuk hadir. (2) Ketua Pengadilan Agama menyampaikan peringatan supaya dalam tempo 8 (delapan) hari dari hari setelah peringatan Termohon eksekusi melakukan isi putusan. (3) Panitera membuat berita acara sidang aanmaning dan ditandatangani oleh Ketua dan Panitera.

e. Apabila dalam tempo 8 (delapan) hari setelah peringatan, Pemohon eksekusi melaporkan bahwa Termohon eksekusi belum melaksanakan isi putusan, Ketua Pengadilan Agama menerbitkan penetapan perintah eksekusi.

5.2.5. Dalam hal eksekusi putusan Pengadilan Agama yang objeknya berada di luar wilayah hukumnya, maka Ketua Pengadilan Agama yang bersangkutan meminta bantuan kepada Ketua Pengadilan Agama yang mewilayahi objek eksekusi tersebut dalam bentuk penetapan. Selanjutnya, Ketua Pengadilan Agama yang diminta bantuan menerbitkan surat penetapan yang berisi perintah kepada Paniera atau Jurusita agar melaksanakan eksekusi di bawah pimpinan Ketua Pengadilan Agama tersebut. (Surat Edaran Mahkamah Agung Nomor 01 Tahun 2010, butir 1).

5.2.6. Dalam hal eksekusi tersebut pada butir (5), diajukan perlawanan baik dari Pelawan tersita maupun dari pihak ketiga, untuk perlawanan tersebut diajukan dan diperiksa serta diputus oleh Pengadilan Agama/Mahkamah Syar'iyah yang diminta bantuan (Pasal 195 ayat (6) HIR/Pasal 206 ayat (6) RBg dan butir (2) Surat Edaran Mahkamah Agung Nomor 01 Tahun 2010).

5.2.7. Dalam hal Pelawan dalam perlawanannya meminta agar eksekusi tersebut pada butir (6) di atas ditangguhkan,maka yang berwenang menangguhkan atau tidak menangguhkan 
eksekusi itu adalah Ketua Pengadilan Agama / Mahkamah Syar'iyah yang diminta bantuannya, sebagai pejabat yang memimpin eksekusi, dengan ketentuan bahwa dalam jangka waktu 2 x 24 jam melaporkan secara tertulis kepada Ketua Pengadilan Agama yang meminta bantuan tentang segala upaya yang telah dijalankan olehnya termasuk adanya penangguhan eksekusi tersebut (Pasal 195 ayat (5) dan (7) HIR/Pasal 206 ayat (5) dan (7) RBg serta butir 3 Surat Edaran Mahkamah Agung Nomor 01 Tahun 2010).

5.2.8. Dalam hal pelaksanaan putusan mengenai suatu perbuatan, apabila tidak dilaksanakan secara sukarela, harus dinilai dalam sejumlah uang (Pasal 225 HIR/Pasal 259 RBg) yang teknis pelaksanaannya seperti eksekusi pembayaran sejumlah uang.

5.2.9. Jika Termohoan tidak mau melaksanakan putusan tersebut dan Pengadilan tidak bisa melaksanakan walau dengan bantuan alat negara, maka Pemohon dapat mengajukan kepada Ketua Pengadilan Agama/Mahkamah Syar'iyah agar Termohon membayar sejumlah uang, yang nilainya sepadan dengan perbuatan yang harus dilakukan oleh Termohon.

5.2.10. Ketua Pengadilan Agama wajib memanggil dan mendengar Termohon eksekusi dan apabila diperlukan dapat meminta keterangan dari seorang ahli di bidang tersebut.

5.2.11. Penetapan jumlah uang yang harus dibayar oleh Termohon dituangkan dalam penetapan Ketua Pengadilan Agama.

5.2.12. Apabila putusan untuk membayar sejumlah uang tidak dilaksanakan secara sukarela, makaakan dilaksanakan dengan cara melelang barang milik pihak yang dikalahkan (Pasal 200 HIR / Pasal 214 s/d Pasal 224 RBg).

5.2.13. Putusan yang menghukum Tergugat untuk menyerahkan sesuatu barang, misalnya sebidang tanah, dilaksanakan oleh 
Jurusita, apabila perlu dengan bantuan alat kekuasaan negara.

5.2.14. Eksekusi tidak bisa dilakukan kedua kalinya apabila barang yang dieksekusi telah diterima oleh Pemohon eksekusi, namun diambil kembali oleh tereksekusi.

5.2.15. Upaya yang dapat ditempuh oleh yang bersangkutan adalah melaporkan hal tersebut di atas kepada pihak yang berwajib (pihak kepolisian) atau mengajukan gugatan untuk memperoleh kembali barang (tanah atau rumah tersebut).

5.2.16. Putusan Pengadilan Agama atas gugatan penyerobotan tersebut apabila diminta dalam petitum, dapat dijatuhkan putusan serta merta atas dasar sengketa bezit/kedudukan berkuasa.

5.2.17. Jika suatu perkara yang telah berkekuatan hukum tetap telah dilaksanakan (dieksekusi) atas suatu barang dengan eksekusi riil, tetapi kemudian putusan yang berkekuatan hukum tetap tersebut dibatalkan oleh putusan peninjauan kembali, maka barang yang telah diserahkan kepada proses gugatan kepada pemilik semula sebagai pemulihan hak.

5.2.18. Pemulihan hak diajukan Pemohon kepada Ketua Pengadilan Agama.

5.2.19. Apabila putusan belum berkekuatan hukum tetap, kemudian terjadi perdamaian di luar Pengadilan yang mengesampingkan amar putusan dan ternyata perdamaian itu diingkari oleh salah satu pihak, maka yang dieksekusi adalah amar putusan yang telah berkekuatan hukum tetap. ${ }^{25}$

Suami memiliki peranan penting dalam pemenuhan biaya keperluan hidup berumah tangga, untuk itu seyogyanya seorang suami harus merealisasikan nafkah tanpa ada beban dan tekanan, karena itu semua

25 Mahkamah Agung RI, Pedoman Pelaksanaan Tugas Dan Administrasi Peradilan Agama; Buku II, . Hlm. 130-133 
adalah konsekuensi logis dari adanya hubungan perkawinan. Namun jika ternyata suami melalaikan kewajibannya untuk memenuhi nafkah istri, maka seorang istri dapat melakukan upaya-upaya hukum, sehingga pemenuhan nafkah istri tetap terlaksana, salah satunya yaitu dengan melakukan gugatan nafkah dan permohonan eksekusi (apabila suami tidak mau melaksanakan putusan dengan suka rela).

Eksekusi adalah hal menjalankan putusan pengadilan yang sudah berkekuatan hukum tetap. Putusan pengadilan yang dieksekusi adalah putusan pengadilan yang mengandung perintah kepada salah satu pihak untuk membayar sejumlah uang, atau menghukum pihak yang kalah untuk membayar sejumlah uang, atau juga pelaksanaan putusan hakim yang memerintahkan pengosongan benda tetap, sedangkan pihak yang kalah tidak mati melaksanakan putusan itu secara sukarela sehingga memerlukan upaya paksa dari pengadilan untuk melaksanakannya. ${ }^{26}$

Sudikno menjelaskan bahwa putusan Pengadilan yang dapat dilaksanakan adalah putusan yang mempunyai kekuatan eksekutorial. Adapun yang memberikan kekuatan eksekutorial pada putusan pengadilan terletak pada putusan yang berbunyi "Demi Keadilan Berdasarkan Ketuhanan Yang Maha Esa”. Di samping itu. putusan pengadilan yang mempunyai titel eksekutorial adalah putusan yang bersifat atau yang mengandung amar "condemnatoir", sedangkan putusan pengadilan yang bersifat "deklaratoir" dan "constitutif” tidak dilaksanakan eksekusi karena tidak memerlukan eksekusi dalam menjalankannya.

Menurut Sudikno Mertokusumo, eksekusi pada hakekatnya tidak lain ialah realisasi dari pada kewajiban pihak yang kalah untuk memenuhi prestasi yang tercantum dalam putusan pengadilan tersebut. Pihak yang menang dapat memohon eksekusi pada pengadilan yang memutus perkara

${ }^{26}$ Abdul Manan, Penerapan Hukum Acara Perdata Di Lingkungan Pradilan Agama. Hlm. 313 
tersebut untuk melaksanakan putusan tersebut secara paksa (execution force). ${ }^{27}$

Suami yang tidak mau melaksanakan kewajibanya untuk membayarkan kewajiban nafkah kepada istri yang telah mengajukan gugatan dan gugatan tersebut telah diputus inkrach atau memiliki kekuatan hukum tetap dari Pengadilan yang memutus perkara, maka dapat dilakukan upaya hukum permohonan eksekusi kepada Pangadilan. Dalam pelaksanaan eksekusi terdapat asas yang harus dipegangi oleh pihak pengadilan, yakni putusan pengadilan harus sudah berkekuatan hukum tetap. Sifat putusan yang sudah berkekuatan hukum tetap adalah tidak ada lagi upaya hukum, dalam bentuk putusan tingkat pertama, bisa juga dalam bentuk putusan tingkat banding dan kasasi. Sifat dan putusan yang sudah berkekuatan hukum tetap adalah litis finiri opperte, maksudnya tidak bisa lagi disengketakan oleh pihak-pihak.

Dalam menjalankan eksekusi terhadap perkara-perkara yang menjadi wewenang Pengadilan Agama, secara umum ada 5 tahapan yang harus di tempuh. Adapun tahapan-tahapan tersebut sebagai berikut:

5.2.1. Permohonan dari pihak istri (ibu) atau anak.

5.2.2. Penaksiran biaya eksekusi.

5.2.3. Melaksanakan peringatan (Aan maning). ${ }^{28}$

5.2.4. Mengeluarkan surat perintah eksekusi.

Apabila waktu yang telah ditentukan dalam peringatan (Aan maning) sudah lewat dan ternyata pihak yang kalah tidak menjalankan putusan, dan tidak mau menghadiri panggilan sidang peringatan tanpa alasan yang sah, maka Ketua Pengadilan Agama mengeluarkan perintah eksekusi dengan ketentuan yaitu: Pertama, perintah eksekusi itu berupa penetapan. Kedua, perintah ditujukan kepada Panitera atau

${ }^{27}$ Sudikno Mertokusumo, Hukum Acara Perdata Indonesia (Yogyakarta: Liberty, 1998). Hlm.

${ }^{28}$ Abdul Manan, Penerapan Hukum Acara Perdata Di Lingkungan Pradilan Agama. Hlm. 317 
Juru Sita. Ketiga, harus menyebut dengan jelas nomor perkara yang hendak dieksekusi dan objek barang yang hendak dieksekusi. Keempat, perintah eksekusi dilakukan di tempat letak barang. Kelima, yaitu isi perintah eksekusi supaya dilaksanakan sesuai dengan amar putusan.

\subsubsection{Pelaksanaan eksekusi}

Perintah eksekusi yang dibuat Ketua Pengadilan Agama, Panitera atau apabila ia berhalangan dapat diwakilkan kepada Juru Sita sebagaimana diatur dalam Pasal 197 ayat (1) HIR dan Pasal 209 R.Bg. Dalam pelaksanaan eksekusi tersebut, Panitera atau Juru Sita dibantu dua orang saksi berumur 21 tahun, jujur dan dapat dipercaya yang berfungsi membantu Panitera atau Juru Sita yang melaksanakan eksekusi. ${ }^{29}$

Berdasarkan penjelasan diatas bahwa pelaksanaan eksekusi gugatan nafkah untuk istri yang tidak mendapatkan nafkah dari suami dapat dituntut oleh istri sebagai konsekuensi dari hak dan kewajiban yang timbul dari akibat hukum adanya suatu perkawinan, istri dapat mengajukan permohonan eksekusi kepada ketua pengadilan apabila suami enggan melaksanakan putusan dengan sukarela dan lalai memenuhi kewajibannya. Eksekusi yang dapat dilakukan adalah terkait dengan gaji atau penghasilan yang kemudian disesuaikan dengan kebutuhan atau keperluan hidup berumah tangga sesuai yang tecantum pada Pasal 34 ayat (1) UndangUndang Nomor 1 Tahun 1974 tentang Perkawinan yang menyatakan bahwa:

"Suami wajib melindungi isterinya dan memberikan segala sesuatu keperluan hidup berumah tangga sesuai dengan kemampuannya".

Setiap putusan Pengadilan perkara perdata idealnya dipatuhi dan dilaksanakan sendiri oleh pihak tergugat. Namun jika tidak demikian, maka hukum acara yang berlaku memberikan jalan yang harus ditempuh oleh

${ }^{29}$ Abdul Manan. Hlm. 313 
pihak penggugat, yaitu melalui permohonan eksekusi. Hal tersebut tidak terlalu menjadi masalah jika memang kewajiban yang harus dipenuhi tergugat tersebut mempunyai nilai yang cukup banyak.

Dalam prakteknya sebagian besar putusan gugatan nafkah mengenai jumlah nominal nafkah istri sebenarnya tidak cukup untuk mengganti biaya rumah tangga yang telah dilalaikan suami. Hakim cenderung menetapkan besarnya nafkah istri disesuaikan dengan kemampuan suami atau karena suami tidak mampu, ditetapkanlah sesuai dengan azas kewajaran dan kepatutan, sebagai upaya melaksanakan Undang-Undang atau berdasarkan hak officio hakim. Pada sisi lain, pengadilan tingkat pertama dalam perkara gugatan nafkah tidak menetapkan kewajiban suami untuk membayar nafkah istri dan anak tetapi ketika perkara tersebut banding dan kasasi, ternyata hakim banding atau hakim tingkat kasasi telah menggunakan hak officio dengan menetapkan angka nominal nafkah anak yang harus dibayar suami.

\section{Kesimpulan}

6.1 Suami dan istri masing-masing memiliki fungsi dan peran masing-masing di dalam menjalankan hidup berumah tangga, seperti yang telah tertuang dalam Pasal 34 ayat (1) dan (2) Undang-Undang Nomor 1 Tahun 1974 tentang Perkawinan dimana suami wajib melindungi istrinya dan memberikan segala sesuatu kebutuhan hidup berumah tangga sesuai dengan kemampuanya yang berarti suami berkewajiban memberikan nafkah untuk istri yang memiliki peran yaitu untuk mengatur urusan rumah tangga sebaik-baiknya. Jadi ketika suami tidak memberikan nafkah kepada istri sesuai dengan Pasal 34 ayat (3) Undang-Undang Nomor 1 Tahun 1974 tentang Perkawinan yang menyebutkan bahwa apabila salah satu pihak didalamnya yaitu suami melalaikan kewajibannya yaitu tidak melaksanakan kewajibannya untuk memberi nafkah kepada istri, maka istri dapat mengajukan gugatan nafkah ke Pengadilan. 
6.2 Gugatan nafkah diajukan dengan surat gugatan yang memuat fakta dan alasan istri menggugat, dengan menyertakan surat nikah sebagai bukti serta bukti-bukti terkait penghasilan suami. Terkait pembuktian surat nikah, apabila surat nikah tersebut ada di tangan suami, kemudian seorang istri dapat meminta duplikat atau salinannya di kantor catatan sipil tempat perkawinan tersebut dilaksanakan. Pembuktian gugatan nafkah meliputi juga jumlah penghasilan suami dan nafkah yang diperlukan untuk diberikan untuk istri dan anak. Istri dapat mengajukan bukti-bukti berupa keterangan 2 (dua) orang saksi, slip gaji suami, dan bukti lainnya, yang menunjukkan sebenarnya suami mempunyai kemampuan untuk memberikan nafkah serta berapa besaran nafkah yang dibutuhkan untuk diberikan kepada istri dan anak. 


\section{DAFTAR PUSTAKA}

\section{Buku}

Abdul Manan. Penerapan Hukum Acara Perdata Di Lingkungan Pradilan Agama. Jakarta: Prenada Media Group, 2005.

Ahrum Hoerudin. Pengadilan Agama Bahasa Tentang Pengajuan Perkara, Dan Kewenangan Pengadilan Agama Setelah Berlakunya Undang-Undang Nomor 7 Tahun 1989 Tentang Praperadilan Agama,. Bandung: PT. Citra Aditya Bakti, 1999.

Ali Yusuf As- Subki. Fiqh Keluarga: Pedoman Berkeluarga Dalam Islam (Terjemahan). Jakarta: Amzah, 2010.

Amir Syarifuddin. Hukum Perkawinan Islam Di Indonesia Antara Fiqh Munakahat Dan Undang-Undang Perkawinan. Jakarta: Kencana, 2007. Bandur, and Agustinus. Penelitian Kualitatif Metodologi, Desain Dan Teknik Analisi Data Dengan NVIVO10. Jakarta: Mitra Wacana Media, 2014.

Basiq Djalil. Peradilan Agama Di Indonesia; Gemuruhnya Plitik Hukum (Hk. Islamm Hk. Barat, Dan Hk. Adat) Dalam Rentang Sejarah Bersama Pasang Surut Lembaga Peradilan Agama Hingga Lahirnya Peradila Syari'at Islam Aceh,. Jakarta: Kencana Prenada Media Group, 2006.

Departemen Agama RI. Ilmu Fiqh, Jilid II. Jakarta: Ditjen Binbaga Islam, 1984.

Erfaniah Zuhriah. Peradilan Agama Indonesia Sejarah Pemikiran Dan Realita. Malang: UIN Malang Press, 2009.

Mahkamah Agung RI. Pedoman Pelaksanaan Tugas Dan Administrasi Peradilan Agama; Buku II,. Jakarta: Direktorat Jenderal Badan Peradilan Agama, 2013.

Mohd. Idris Ramulyo. Hukum Perkawinan Islam Suatu Analisis Dari UndangUndang Nomor 1 Tahun 1974 Dan Kompilasi Hukum Islam. Jakarta: PT Bumi Aksara, 2002.

Satria Effendi. Problematika Hukum Keluarga Islam Kontemporer,. Jakarta: Kencana Prenada Media Group, 2004.

Sudikno Mertokusumo. Hukum Acara Perdata Indonesia. Yogyakarta: Liberty, 
1998.

Syaikh Mahmud Al-Mashri. Perkawinan Idaman (Terjemahan). Jakarta: Qitho Press, 2011.

Wasman, and Wardah Nuroniah. Hukum Perkawinan Islam Di Indonesia, Perbandingan Fikih Dan Hukum Positif. Yogyakarta: Teras, 2011.

\section{Artrikel Jurnal}

Tri Lisiani Prihatinah. "Tinjauan Filosofis Undang-Undang Nomor 1 Tahun 1974.” Jurnal Dinamika Hukum, 8, no. 2 (2008).

\section{Peraturan Perundang-undangan.}

Undang-Undang Nomor 1 Tahun 1974 tentang Perkawinan.

Undang-Undang Nomor 23 Tahun 2002 tentang Perlindungan Anak .

Surat Edaran Mahkamah Agung Nomor 01 Tahun 2010.

Keputusan Ketua Mahkamah Agung Nomor 026/KMA/ SK/II/2012 Tentang Standar Pelayanan Peradilan.

H.I.R (Het Herziene Indonesisch Reglement).

Kompilasi Hukum Islam (KHI).

\section{Media Online}

http://www.hukumonline.com/berita/baca/hol17429/kejarlah-nafkah-sampai-kepengadilan, diakses tanggal 19 Agustus 2018

https://www.hukumonline.com/klinik/detail/ulasan/lt54dc068b67d8e/bisakahmengajukan-gugatan-nafkah-tanpa-cerai, diakses tanggal 3April 2019

http://www.hukumonline.com/berita/baca/hol17429/kejarlah-nafkah-sampai-kepengadilan, diakses tanggal 19 Agustus 2018

https://www.hukumonline.com/klinik/detail/ulasan/lt54dc068b67d8e/bisakahmengajukan-gugatan-nafkah-tanpa-cerai, diakses tanggal 3 April 2019 